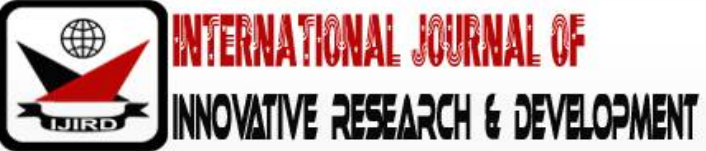

ISSN 2278-0211 (Online)

\section{Access to Curriculum Content and Students' Academic Performance in the Sciences in Rural and Urban Public High Schools in the South West Region of Cameroon}

\begin{tabular}{|c|}
\hline Dr. Endeley Margaret Nalova \\
Associate Professor, Department of Curriculum Studies and Teaching, \\
University of Buea, Cameroon \\
Dr. Mbanjo Martin Ewange \\
Assistant Lecturer, Department of Curriculum Studies and Teaching, \\
University of Buea, Cameroon \\
\hline
\end{tabular}

\section{Abstract:}

The study investigated students' access to the science curriculum and their academic performance in the rural and urban areas. 360 upper sixth rural and urban public high school students offering Biology, Chemistry and Physics participated in the study. The causal comparative research design was used with a questionnaire, an observation check list and a focus group discussion guide as instruments. Descriptive and inferential statistics were used to analyse data. Findings revealed that the availability of curriculum content has a high significant influence on students' performance and is greater in urban areas than in rural areas. Recommendations were made.

Keywords: Curriculum access, content, access, academic performance, secondary school, urban and rural

\section{Introduction}

The effective teaching and learning of the sciences in the high school depends very much on the availability of curriculum content at the disposal of teachers and students. Bilbao et al, (2008) and Tambo, (2012) define curriculum content as the information on the laws, principles, concepts, theories, phenomena, and generalizations that make up the subject matter of the various disciplines. Curriculum content is simply the body of information which is taught and learned in school. Itis often said that "knowledge is power" and since information is the source of knowledge, it implies that curriculum content is the source of all the knowledge, skills and attitudes which is learned and acquired in school. This in effect means that the teaching and learning of science would be very difficult if not impossible without students' access to curriculum content given that information is the source of knowledge. The availability of curriculum content appears not to be the same for students in all locations. This may affect students' access to the science curriculum which might consequently affect their academic performance. It is on this basis that this study attempted to investigate students' access to curriculum content in the sciences and its influence on their academic performance in rural and urban public high schools in the South West Region of Cameroon.

\section{Review of Literature}

Access to curriculum content may affect students learning and consequently their academic performance. Akende and Bamise, (2017) argue that the source and access to information can influence the academic performance of secondary school students. An important factor that influences access to content is school location. Students in schools located in urban areas seem to have greater access to curriculum content than students in schools located in rural areas (Carlsen and Monk, 1992).

The subjects- Biology, Chemistry and Physics are very important in that they provide the content base or body of information which serve as the source of knowledge to be taught and learned in school. Biology has been defined by Rogers, as the study of living things and their vital processes (Green and Joshi (2018). Knowledge and skills in Biology are therefore required to build a solid foundation for future career in medicine, agriculture, nutrition and others. Helmenstine (2019), defines Chemistry as the science that systematically studies the composition, properties, and activity of organic and inorganic substances and various elementary forms of matter. Knowledge and skills in Chemistry is required to build a solid foundation for future career in medicine, agriculture, biochemical, chemical and petro-chemical engineering amongst others.

Brown and Weidner (2019), define Physics as the science that studies the structure of matter and the interactions between the fundamental constituents of the observable universe. Rogers, Green and Joshi, (2018) assert that Physics provides the content or information which attempt to explain the reasons and provide deeper reflections about the 
occurrences of natural phenomena like electricity, magnetism, electronics, gravitation, mechanics and more. Knowledge and skills in Physics is therefore required to build a solid foundation for future career in medicine, mechanical engineering, electrical engineering etc. Scientific knowledge in Biology, Chemistry and Physics overlap with each other. For this reason, the subjects are sometimes integrated or merged to form larger disciplines otherwise referred to as broad field.

The availability of curriculum content can be measured by examining two sub indicators namely the sources from which content can be drawn as well as syllabus courage.

\subsection{Sources from Which Content Can Be Drawn}

Akende and Bamise (2017), argue that, the source and access to information can influence the academic performance of secondary school students. The various sources from which content can be drawn include the school library, text books, the internet etc. A library as is room or building in which all the learning materials such as books, tape, newspapers are available for people to study, learn and borrow. The Library facility is an essential component in the education process and its availability in school makes the teaching learning process more effective and advanced (Ayaz et al, 2017).

The school library plays a pivotal role in any educational system and give supports and guidance to the readers. Fowowo (1988), stated that the school library should be well equipped and accessible to all students and teachers. Ullah \& Farrog (2008), assert that reading of library materials have a positive relationship with students' vocabulary, grammar, comprehension, writing and spelling skills. These abilities need a well- managed library where they improve their skills and academic performance. Ola (1990) suggested that a sound prepared library collection is a foremost facility that enhances high quality education and achievement of high learning standard.

Fuller (1986), observed that the school library is the source which has significant relation with students' academic achievement. Popoola (1989), revealed that library has a correlation with students' performance and schools which have a well operational library facility usually preserve high academic achievement. According to Keith (2004) the availability of school libraries helps teachers to teach the students effectively. Clark (1999) asserted that the school library basically is the academic library which supports the entire school program and also help in the teaching learning process. He further explained that the availability of an adequate library facility improves the learning environment and makes the process effective and easy.

Keith (2004), observed that those students who were always attending library, got more score as compared to those who were not. Adomi (2006), observed that the school library has significant importance for both students and teachers. In the same vein, Nambuya (2013), revealed that the availability of physical resources such as library and textbooks affect the academic performance of students. The literature reviewed reveals that students who attend schools with good libraries and make good use of it will have greater access to curriculum content leading to better performance than students in schools with poorly equipped libraries.

Another important source from which students can draw or access subject matter- content is the internet. The internet is a network of computers which are interconnected in a manner which permits them to share or access information amongst them. Kumah (2015), found that, updated and current information is well organized on the internet for easy search and has contributed significantly to students' academic laurels. Ogedebe (2012) observed that majority of the students obtain relevant information such as academic materials from the internet. This according to him suggests that, students use the internet to enhance their study. The internet helps students to broaden their academic knowledge, research and assignment by accessing information worldwide (Siraj et al 2015).

Ogedebe (2012), found out that the GPAs of respondents increased significantly as a result of the use of the internet and many respondents attest that the internet aids them in preparing for CAs and semester examination. This equally implies that students who have the opportunity to access the internet might perform better than those who do not have such an opportunity. Thus, the availability of alternative sources to draw content might enhance students' access to the high school science curriculum

\subsection{Syllabus Coverage}

The extent to which students cover the syllabuses of Biology, Chemistry and Physics greatly determines their level of access to the high school science curriculum which might consequently affect their academic performance.

Nakhanu (2012), carried out a study to investigate the effect of syllabus coverage on students' academic performance in secondary school mathematics in Kenya and found that students who cover the mathematics syllabus, have a better mean score than those who fail to cover the syllabus. These findings are in line with the 2005 KNEC report, which indicated that when the syllabus is inadequately covered, it might lead to poor access to curriculum content which might consequently affect students' performance negatively and vice versa. Mwiria (1985), found out that students who have access to text books, internet and other instructional resources complete their assignments and syllabus which enhances their academic performance. Thus, students in schools with high syllabus coverage might have greater access to the high school science curriculum than those in schools with low syllabus coverage.

\subsection{Access to the High School Science Curriculum in Urban and Rural Areas}

Wallin and Reiner (2008), found out that rural schools are often plagued with educational problems such as isolation from specialized services, limited accessibility to quality staff development and university services, teacher shortages and decreasing enrolments which lead to decreased funding. Pierre du Plessis (2014) observed that rural areas are characterized by various factors that negatively influence the delivery of quality education. They presented the following findings as significant challenges and problems hampering the development of rural schools in Mpumalang, 
South Africa: Constraints of role multiplicity, problems of access in rural schools, challenges of technology, lack of resources and amongst others.

\section{Statement of the Problem}

Students' performance in the Sciences at the General Certificate of Education (GCE) Advance Level calls for improvement. While it is not so bad in Biology, performance in Chemistry has been mediocre and below average in Physics in the last five years. Many factors could account for this. However, access to the curriculum due to the location of the school is a factor that has received very little attention. Teaching and learning in some rural areas in the South West region of Cameroon is very challenging. Some rural areas don't have electricity and mobile telephone network thus retarding the installation of the internet. Many of these areas are inaccessible due to extremely bad roads which may account for the lack of libraries and laboratories in schools located in such areas. Due to the challenges of accessing and living in rural areas, some teachers who are sent to schools in these areas abandon their duty and return to town, resulting to an acute shortage of qualified teachers. The few who are left there are consequently overburdened with obvious consequences on content coverage. Thus, students' access to the science curriculum in such areas might be further affected given the acute shortages of teaching/learning resources like school laboratories and libraries. The absence of equipped libraries and internet facilities in some schools put students in such areas at a disadvantage relative to students in schools which are endowed with these facilities. Thus, the study investigated the extent to which the availability of curriculum content affects students' academic performance in the sciences in rural and urban public high schools in the South West Region of Cameroon.

\subsection{Research Question}

- To what extent does the availability of curriculum content affect students' academic performance in the sciences in rural and urban public schools in the South West Region of Cameroon?

\subsection{Hypothesis}

- The availability of curriculum content in rural and urban areas has no significant influence on students' academic performance.

\section{Methodology}

The study made use of the causal comparative research design which permitted the collection of data from the two groups of students (rural and urban), analysed and compared it to establish the reason or cause for the difference in performance (if any exist) between the two groups. The area of this study was limited to the South West Region of Cameroon. The study effectively involved public high schools found in both the Urban and Rural areas of Fako, Meme and Manyu divisions of the South West Region of Cameroon. The study involved a sample of 360 upper sixth science students offering Biology, Chemistry and Physics drawn from rural and urban public high schools. The instruments used for data collection included a questionnaire, an observation check list, a focus group discussion guide as well as records on students' performance (student's regional mock results). Both descriptive and inferential statistics were used to analyse data. The Pearson correlation coefficient moment $(r)$ was used to test the hypothesis. The data collected by the focus group discussion was analysed using thematic (content) analysis, while the data from the observation check list was analysed using descriptive statistics with the use of frequencies and percentages.

\section{Findings}

Research Question: To what extent does the availability of curriculum content affect students' academic performance in the sciences in rural and urban public schools in the South West Region of Cameroon?

\begin{tabular}{|c|c|c|c|c|c|c|}
\hline Variables of Interest & N & Df & Text Statistics & $\boldsymbol{\tau}$-comp & $\begin{array}{c}\text { Maximum } \\
\text { Value }\end{array}$ & Magnitude \\
\hline $\begin{array}{c}\text { Availability of } \\
\text { curriculum content }\end{array}$ & 347 & 345 & $\begin{array}{c}\text { Pearson } \\
\text { correlation }(\tau)\end{array}$ & 0.683 & 1 & Moderate \\
\hline $\begin{array}{c}\text { Students' Academic } \\
\text { Performance }\end{array}$ & & & & & \\
\hline
\end{tabular}

Table 1: Summary Extracts from SPSS Analyses Relating to Response to Research Question

Results on Table 1 show that $\tau$-computed value (0.683) was determined at alpha level of significance of 0.05 with degree of freedom 345. Since $\tau$-compupted value (0.683) lies within 0.068 and 1 , the magnitude is high. This implies that the availability of curriculum content highly affects students' academic performance in the positive direction. 


\begin{tabular}{|c|c|c|}
\hline Questions & $\begin{array}{l}\text { Responses from Urban } \\
\text { Schools }\end{array}$ & $\begin{array}{c}\text { Responses from Rural } \\
\text { Schools }\end{array}$ \\
\hline $\begin{array}{l}\text { What sources do you draw subject } \\
\text { matter content for teaching }\end{array}$ & $\begin{array}{c}\text { Textbooks, manuals, } \\
\text { internet facilities, } \\
\text { schemes of work }\end{array}$ & $\begin{array}{c}\text { Scheme of work, } \\
\text { manuals, textbooks }\end{array}$ \\
\hline $\begin{array}{l}\text { Besides classroom interactions, do } \\
\text { students have other alternative sources } \\
\text { from which they access subject matter } \\
\text { (content) for learning? }\end{array}$ & Yes & $\begin{array}{l}\text { Yes, although limited in } \\
\text { supply }\end{array}$ \\
\hline If yes, state the sources & $\begin{array}{c}\text { From textbooks in the } \\
\text { School library and } \\
\text { internet services }\end{array}$ & Textbooks \\
\hline \multicolumn{3}{|l|}{$\begin{array}{l}\text { How do you rate the syllabus coverage } \\
\text { for the following science subjects }\end{array}$} \\
\hline Biology & High and good (90-100\%) & Good (above 65\%) \\
\hline Chemistry & High and good (90-100\%) & Good (above 60\%) \\
\hline Physics & High and good (90-100\%) & Good (above 60\%) \\
\hline
\end{tabular}

Table 2: Responses Registered During the Focus Group Discussion on the Availability of Curriculum Content

Results on Table 2 show the responses registered during the focus group discussion on the availability of curriculum content. From the analysis, curriculum content is more available in schools in the urban location than those in the rural location.

\begin{tabular}{|c|c|c|c|c|c|c|c|c|c|c|c|c|c|c|}
\hline \multirow{2}{*}{$\begin{array}{c}\text { Location of } \\
\text { School }\end{array}$} & \multirow[t]{2}{*}{ Subjects } & \multirow{2}{*}{$\begin{array}{c}\text { Aspects } \\
\text { Observed }\end{array}$} & \multicolumn{2}{|c|}{ VG } & \multicolumn{2}{|c|}{$\mathbf{G}$} & \multicolumn{2}{|c|}{$\mathbf{A}$} & \multicolumn{2}{|c|}{$\mathbf{F}$} & \multicolumn{2}{|c|}{$\mathbf{N}$} & \multicolumn{2}{|c|}{ TOTAL } \\
\hline & & & $\mathbf{F}$ & $\%$ & $\mathbf{F}$ & $\%$ & $\mathbf{F}$ & $\%$ & f & $\%$ & f & $\mathbf{F}$ & f & $\%$ \\
\hline \multirow[t]{4}{*}{ Urban } & \multirow[t]{4}{*}{ Biology } & $\begin{array}{l}\text { Students } \\
\text { copy notes } \\
\text { and draw } \\
\text { diagrams } \\
\text { presented } \\
\text { by the } \\
\text { teacher } \\
\text { during the } \\
\text { teaching/ } \\
\text { learning } \\
\text { process. }\end{array}$ & 3 & 100 & - & - & - & - & - & - & $\ldots-$ & - & 3 & 100 \\
\hline & & $\begin{array}{l}\text { Students get } \\
\text { materials } \\
\text { from text } \\
\text { books in the } \\
\text { school } \\
\text { library to do } \\
\text { assignments. }\end{array}$ & - & - & 3 & 100 & - & - & - & - & - & - & 3 & 100 \\
\hline & & $\begin{array}{c}\text { Students } \\
\text { download } \\
\text { materials } \\
\text { from the } \\
\text { internet to } \\
\text { study and to } \\
\text { do } \\
\text { assignments }\end{array}$ & 2 & 66.7 & 1 & 33.3 & - & - & - & - & - & - & 3 & 100 \\
\hline & & $\begin{array}{c}\text { Topics } \\
\text { covered for } \\
\text { Biology } 10 \\
\text { Out of } 11 \\
\text { Thus } \\
\text { syllabus } \\
\text { (content) } \\
\text { Coverage = } \\
90.9 \%\end{array}$ & & & & & & & & & & & & \\
\hline
\end{tabular}




\begin{tabular}{|c|c|c|c|c|c|c|c|c|c|c|c|c|c|c|}
\hline \multirow{2}{*}{$\begin{array}{l}\text { Location of } \\
\text { School }\end{array}$} & \multirow[t]{2}{*}{ Subjects } & \multirow{2}{*}{$\begin{array}{c}\text { Aspects } \\
\text { Observed }\end{array}$} & \multicolumn{2}{|c|}{ VG } & \multicolumn{2}{|c|}{$\mathbf{G}$} & \multicolumn{2}{|c|}{ A } & \multicolumn{2}{|c|}{$\mathbf{F}$} & \multicolumn{2}{|c|}{$\mathbf{N}$} & \multicolumn{2}{|c|}{ TOTAL } \\
\hline & & & $\mathbf{F}$ & $\%$ & $\mathbf{F}$ & $\%$ & f & $\%$ & f & $\%$ & $\mathbf{F}$ & $\mathbf{F}$ & f & $\%$ \\
\hline \multirow[t]{5}{*}{ Rural } & \multirow[t]{5}{*}{ Biology } & $\begin{array}{l}\text { Students } \\
\text { copy notes } \\
\text { and draw } \\
\text { diagrams } \\
\text { presented } \\
\text { by the } \\
\text { teacher } \\
\text { during the } \\
\text { teaching. } \\
\text { Learning } \\
\text { process }\end{array}$ & - & - & 3 & 100 & - & - & - & - & - & - & 3 & 100 \\
\hline & & $\begin{array}{l}\text { Students get } \\
\text { materials } \\
\text { from } \\
\text { textbooks to } \\
\text { do } \\
\text { assignments }\end{array}$ & - & - & - & - & 3 & 100 & - & - & - & - & 3 & 100 \\
\hline & & $\begin{array}{l}\text { Students } \\
\text { download } \\
\text { materials } \\
\text { from the } \\
\text { internet to } \\
\text { study and do } \\
\text { assignments }\end{array}$ & - & - & - & - & - & - & - & - & 3 & 100 & 3 & 100 \\
\hline & & $\begin{array}{c}\text { Topics } \\
\text { covered for } \\
\text { biology } 7 \\
\text { out of } 11 \\
\end{array}$ & & & & & & & & & & & & \\
\hline & & $\begin{array}{c}\text { Thus } \\
\text { syllabus } \\
\text { (content) } \\
\text { Coverage in } \\
\text { Biology = } \\
63.6 \%\end{array}$ & & & & & & & & & & & & \\
\hline
\end{tabular}

Table 3: Analyses of the Observation (A) Checklist Relating to the Availability of the Biology Curriculum Content

The results on Table 3 show that the availability of curriculum content in Biology is greater in schools in urban locations than those in rural locations which resulted to a higher syllabus coverage in urban locations than in rural location.

Continuation of Table 4 on the Analyses of the observation (A) checklist relating to the availability of the Chemistry Curriculum Content.

\begin{tabular}{|c|c|c|c|c|c|c|c|c|c|c|c|c|c|c|}
\hline \multirow{2}{*}{$\begin{array}{l}\text { Location } \\
\text { of School }\end{array}$} & \multirow[t]{2}{*}{ Subjects } & \multirow{2}{*}{$\begin{array}{l}\text { Aspects } \\
\text { Observed }\end{array}$} & \multicolumn{2}{|c|}{ VG } & \multicolumn{2}{|c|}{ G } & \multicolumn{2}{|c|}{ A } & \multicolumn{2}{|c|}{$\mathbf{F}$} & \multicolumn{2}{|c|}{$\mathbf{N}$} & \multicolumn{2}{|c|}{ Total } \\
\hline & & & $\mathbf{F}$ & $\%$ & $\mathbf{F}$ & $\%$ & $\mathbf{F}$ & $\%$ & f & $\%$ & f & $\mathbf{F}$ & f & $\%$ \\
\hline Urban & Chemistry & $\begin{array}{l}\text { Students copy } \\
\text { notes and } \\
\text { draw } \\
\text { diagrams } \\
\text { presented by } \\
\text { the teacher } \\
\text { during the } \\
\text { teaching/ } \\
\text { learning } \\
\text { process. }\end{array}$ & 3 & 100 & & & - & - & - & - & $\ldots-$ & - & 3 & 100 \\
\hline & & $\begin{array}{l}\text { Students get } \\
\text { materials } \\
\text { from text } \\
\text { books in the } \\
\text { school library } \\
\text { to do } \\
\text { assignments. }\end{array}$ & - & - & 3 & 100 & - & - & - & - & - & - & 3 & 100 \\
\hline
\end{tabular}




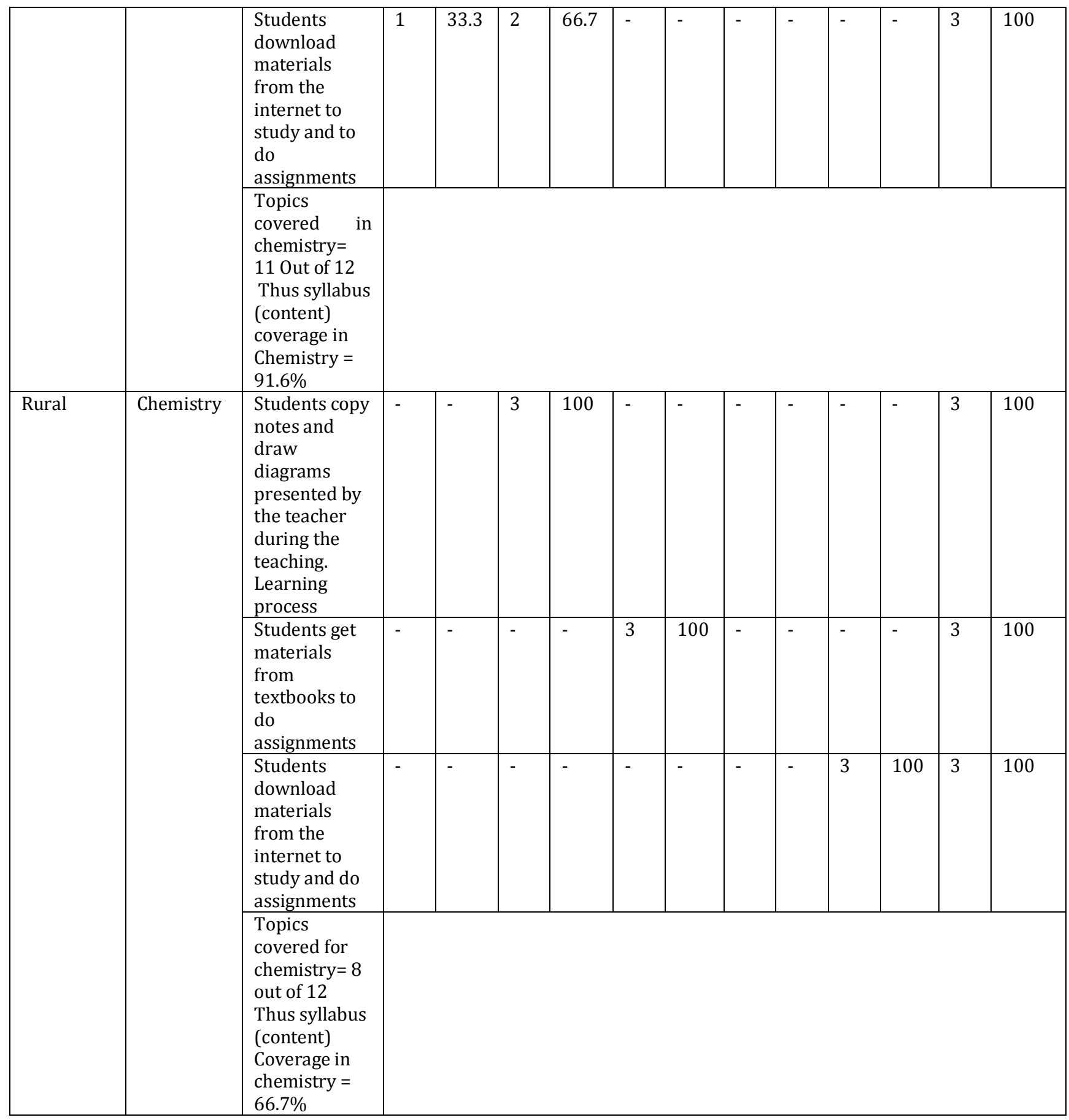

Table 4: Analyses of the Observation (A) Checklist Relating to the Availability of the Chemistry Curriculum Content

Results on Table 4 show that the availability of curriculum content in Chemistry is greater in schools in urban locations than those in rural locations which resulted to a higher syllabus coverage in urban locations than in rural location.

Continuation of Table 5 on the Analyses of the observation (A) checklist relating to the availability of Physics Curriculum Content. 


\begin{tabular}{|c|c|c|c|c|c|c|c|c|c|c|c|c|c|c|}
\hline \multirow{2}{*}{$\begin{array}{l}\text { Location } \\
\text { of School }\end{array}$} & \multirow[t]{2}{*}{ Subjects } & \multirow{2}{*}{$\begin{array}{c}\text { Aspects } \\
\text { Observed }\end{array}$} & \multicolumn{2}{|c|}{ VG } & \multicolumn{2}{|c|}{ G } & \multicolumn{2}{|c|}{ A } & \multicolumn{2}{|c|}{$\mathbf{F}$} & \multicolumn{2}{|c|}{$\mathbf{N}$} & \multicolumn{2}{|c|}{ TOTAL } \\
\hline & & & $\mathbf{F}$ & $\%$ & $\mathbf{F}$ & $\%$ & $\mathbf{F}$ & $\%$ & $\mathbf{f}$ & $\%$ & f & $\mathbf{F}$ & f & $\%$ \\
\hline \multirow[t]{4}{*}{ Urban } & \multirow[t]{4}{*}{ Physics } & $\begin{array}{c}\text { Students copy } \\
\text { notes and } \\
\text { draw } \\
\text { diagrams } \\
\text { presented by } \\
\text { the teacher } \\
\text { during the } \\
\text { teaching/ } \\
\text { learning } \\
\text { process. }\end{array}$ & 3 & 100 & - & - & - & - & - & - & ...- & - & 3 & 100 \\
\hline & & $\begin{array}{l}\text { Students get } \\
\text { materials from } \\
\text { text books in } \\
\text { the school } \\
\text { library to do } \\
\text { assignments. }\end{array}$ & - & - & 3 & 100 & - & - & - & - & - & - & 3 & 100 \\
\hline & & $\begin{array}{c}\text { Students } \\
\text { download } \\
\text { materials from } \\
\text { the internet to } \\
\text { study and to } \\
\text { do } \\
\text { assignments }\end{array}$ & 1 & 33.3 & 2 & 66.7 & - & - & - & - & - & - & 3 & 100 \\
\hline & & $\begin{array}{c}\text { Topics } \\
\text { covered in for } \\
\text { physics = } 12 \\
\text { Out of } 12 \\
\text { Thus syllabus } \\
\text { (content) } \\
\text { Coverage in } \\
\text { Physics = } \\
100.0 \%\end{array}$ & & & & & & & & & & & & \\
\hline \multirow[t]{4}{*}{ Rural } & \multirow[t]{4}{*}{ Physics } & $\begin{array}{c}\text { Students copy } \\
\text { notes and } \\
\text { draw } \\
\text { diagrams } \\
\text { presented by } \\
\text { the teacher } \\
\text { during the } \\
\text { teaching. } \\
\text { Learning } \\
\text { process }\end{array}$ & - & - & 3 & 100 & - & - & - & - & - & - & 3 & 100 \\
\hline & & $\begin{array}{c}\text { Students get } \\
\text { materials from } \\
\text { textbooks to } \\
\text { do } \\
\text { assignments }\end{array}$ & - & - & - & - & 3 & 100 & - & - & - & - & 3 & 100 \\
\hline & & $\begin{array}{c}\text { Students } \\
\text { download } \\
\text { materials from } \\
\text { the internet to } \\
\text { study and do } \\
\text { assignments }\end{array}$ & - & - & - & - & - & - & - & - & 3 & 100 & 3 & 100 \\
\hline & & $\begin{array}{c}\text { Topics } \\
\text { covered for } \\
\text { Physics = } 8 \\
\text { out of } 12 \\
\text { Thus syllabus } \\
\text { (content) } \\
\text { Coverage in } \\
\text { Physics = } \\
66.7 \%\end{array}$ & & & & & & & & & & & & \\
\hline
\end{tabular}

Table 5: Analyses of the Observation (A) Checklist Relating to the Availability of Physics Curriculum Content

Results on Table 5 show that the availability of curriculum content in Physics is greater in schools in urban locations than those in rural locations which resulted to a higher syllabus coverage in urban locations than in rural location. 


\subsection{Hypothesis Testing}

- Hypothesis: The availability of curriculum content has no significant influence on students' academic performance in rural and urban schools

\begin{tabular}{|c|c|c|c|c|c|c|c|}
\hline Variable of the study & $\mathbf{N}$ & $d f$ & $\begin{array}{l}\sum x \\
\sum y\end{array}$ & $\begin{array}{l}\sum x^{2} \\
\sum y^{2}\end{array}$ & $\sum x y$ & r-comp. & $\begin{array}{l}\text { rxy- } \\
\text { crit. }\end{array}$ \\
\hline $\begin{array}{l}\text { Availability of curriculum } \\
\text { content }\end{array}$ & 347 & 345 & 5271 & 66747 & 43557 & 0.683 & 0.073 \\
\hline $\begin{array}{l}\text { Students' academic } \\
\text { performance }\end{array}$ & & & 2264 & 31512 & & & \\
\hline
\end{tabular}

Table 5: Summary Table of SPSS Analysis Relating to Testing Hypothesis

$P=0.05$

\subsubsection{Verification of Hypothesis}

Results on Table 6 shows that, at alpha level of significance of 0.05 with degree of freedom 345, the r-computed value $(0.683)$ was greater than the r-critical value $(0.073)$. This led to the rejection of the null hypothesis and retention of the alternative form. The conclusion drawn was that, the availability of curriculum content has a significant influence on students' academic performance in rural and urban schools.

\begin{tabular}{|c|c|c|c|c|c|c|}
\hline $\begin{array}{c}\text { School } \\
\text { Location }\end{array}$ & N & Df & $\begin{array}{c}\text { Mean(x) Perform } \\
\text { for Bio, Chem To } \\
\text { phy }\end{array}$ & $\begin{array}{c}\text { Stand } \\
\text { Dev }\end{array}$ & Test statistic & $\begin{array}{c}\text { Difference } \\
\text { in Mean }\end{array}$ \\
\hline Urban & 105 & 104 & 13.69 & 1.0061 & $\begin{array}{c}\text { 2-sample } \\
\text { independent t- } \\
\text { test }\end{array}$ & 2.13 \\
\hline Rural & 105 & 104 & 11.56 & 0.9931 & & \\
\hline
\end{tabular}

Table 6: Summary of Findings for Means of Schools in Urban and Those in Rural Zones

$$
P=0.05
$$

With the alpha level of significance of 0.05 , when the difference in the mean performance in urban and rural schools was computed, the value was a significant difference of 2.13 with urban schools having a mean score of 13.69 and rural schools having a mean of 11.56 .

Summarily the availability of curriculum content has a high significant influence on students' academic performance in the rural and urban areas by a high significant $r$-computed value of 0.683 . The findings also showed that curriculum content is more available in urban areas than rural areas giving urban school students a better access to curriculum content than those in rural areas.

\section{Discussion}

The comparatively better performance of urban school students as against their rural counterparts is a confirmation to the fact that the availability of curriculum content has a significant influence on student's academic performances, since the availability of curriculum content is greater for students in urban schools due to their greater exposure to alternative sources of content and greater syllabus coverage than students in rural areas. The alternative sources from which students in urban schools draw subject matter-contents according to the findings include teacher's notes, the school library, textbooks and internet facilities, where as those in rural areas rely mostly on the teacher's notes and textbooks. In line with this, many empirical studies (e.g. Ruth and Adetolun, 2015; Akende and Bamise, 2017), report that, the source and access to information can influence the academic performance of secondary school students. For example, physical resources like libraries and textbooks positively affects students' academic performance (Nambuya, 2013; Popoola, 1989; Ola,1990 and Fuller, 1986).

Access to the internet has also shown to be very instrumental to students' achievement. In this light, Kumah (2015), found that updated and current information is well organized on the internet for easy search and has contributed significantly to students' academic laurels. It is therefore not surprising when students in urban schools perform better than those in rural areas. This is probably because of the greater understanding derived from their exposure to current and well-organized alternative sources of content than students in rural areas. Similar findings are reported by TorresDiaz et al., (2016); Siraj et al (2015); Mami and Hatami-Zad, (2014) Ogedebe, (2012); Chen and Fu (2009) and Kumar and Kaur, (2006). In addition, Amaoge and Igwebuike (2016), believe that the internet has increasingly become an invariable asset in education in terms of learning, teaching and research. This is probably the reason for the better performance registered by urban school students as against their rural counterparts since students in urban areas have greater access to internet facilities than those in rural areas.

The findings also revealed that, syllabus coverage for Biology, Chemistry and Physics is higher for urban schools relative to rural schools. The higher syllabus coverage gives students in urban school's greater access to curriculum content leading to better students' performance than in rural schools with lower syllabus coverage. To support this Nakhanu (2012) and Mwiria (1985) in separate studies found that, students who cover the syllabus have a better mean score than those who fail to cover the syllabus. This is what probably accounts for the better performance by urban school students relative to their rural counterparts given that they have higher syllabus coverage than schools in rural areas. 
Access to curriculum content has shown to be associated with the following benefits: Teachers and students will access what is needed to be learned even on their own at home; High coverage of content (syllabus) is ensured; Mastery of content is ensured; Assurance for success is equally ensured. Students who have greater access to subject matter content are more exposed to these benefits. This is probably the reason why students in urban schools perform better than those in rural areas since they have greater access to subject matter content from multiple sources such as the school library, textbooks and the internet and also due to higher syllabus coverage than students in rural areas. To buttress this, Mwiria (1985) found that the availability of textbooks, teacher's guides, reference books, computers and internet enables learners to complete assignments, cover the syllabus adequately and consequently improved academic results. Therefore, lack or insufficient supply of these facilities can result to poor or low performances. Findings from studies done by Carron and Chou (1996) in India and Williams (2000) in Latin America indicated that acute shortage of school facilities such as inadequate library led to poor academic performance in the areas most affected by this problem in these countries. Thus, the availability and use of textbooks, libraries and the internet have shown to be very instrumental in enhancing learning and student's performance. Also, Ali, Haolader and Muhammed (2013), stated that in classroom teaching and learning, the use of ICT and internet is imperative as it give chance to the instructors and learners to operate, store, control, retrieve data and even engage in learning after school time.

The findings from this study and many others have shown that the availability of curriculum content positively affects students' academic performance.

\section{Recommendations}

The government should consider increasing access to curriculum content or subject matter by putting in place policies that will ensure the increase and upgrading of school libraries with current textbooks as well as the putting in place of internet facilities in all schools particularly in the rural areas where acute shortages are reported to enable students and teachers access subject matter-content for effective learning. Other stakeholders like proprietors, Head teachers, elites, Parent Teacher Associations (PTA) the business community should endeavour to support schools with libraries, qualified teachers and other resources. Also, good performance in the sciences should be rewarded through scholarships and prize-award ceremonies.

Students should also make good use of educational facilities at their disposal for example they should explore the library and the internet to access curriculum content or subject matter for effective learning. They should also explore these facilities to ensure greater and effective coverage of curriculum content

\section{References}

i. Adomi, E. E. (2006). Collection development and management in context. Warri: Etodick Publishers. Retrieved from https://www.scribd.com/pdf on 24/04/2019.

ii. Akande, S. O. and Bamise, O. F. (2017). The Role of School Library in Academic Motivation of Secondary School Students in Osun State, Nigeria. International Journal of Library Science. Scientific \& Academic Publishing,

iii. Ali, M. M., Haolader, T and Muhammed H. (2013). Internet usage among students and teachers: An exploratory study. International Journal of Advanced Research in Computer Science and Software Engineering, 3(6), 125135.

iv. Amaoge, D. A.and Igwebuike E U. (2016). Assessment of Internet Awareness and Use by the Undergraduate Students of College of Agricultural and Science Education in Michael Okpara University of Agriculture Umudike American Journal of Educational ResearchVol. 4, No. 2, 2016, pp 200-203. doi: 10.12691/education-4-2-8 | Research Article

v. Ayaz, M., Ali, N., Khan, A. B., Ullah, R. and Ullah, M. (2017). Impact of school library on students' Academic Achievement of secondary school level in Southern district of Khyber Pakhtunkhwa. International Journal of academic research in Business and social sciences, 7 (5). ISS N: 2222-6990

vi. Bilbao, P. P., Lucido, P. L., Iringan, T. C. and Javier, R. B. (2008). Curriculum development. Philippines: Lorimar Publishing. Inc. Retrieved from https://journals.sagepub.comon 12/02/2019.

vii. Brown, L. M. and Weidner, R. T. (2019). Physics. Retrieved from https://www.britannica.com/science/physicsscience. on 24/04/2019

viii. Carlsen, W. S. and Monk, D. H. (1992). Rural / non rural differences among secondary science teachers: Evidence from the longitudinal study of American Youth. paper presented at the annual meeting of the American educational research association san Francisco Retrieved fromhttps://www.researchgate.net on 12/02/2019

ix. Carron, G. \& Chau, T. N. (1996): The quality of primary schools in different development contexts. Paris: UNESCO

X. Clarke, S. O. (1999). Fundamentals of library science. Lagos: Functional publishers.

xi. Fowowe, S. O. (1988). Finding Academic Libraries in Nigeria: A survey of some Nigerian University libraries. Ilorin Journal of Education, 8, 21-16

xii. Fuller, B. (1985). Raising school quality in developing countries: what investments Boost learning (Education and Training series, Discussion paper number (EDT) Washington, D. C.: World Bank. Retrieved from http://www.sciences-en-ligne.com on 24/04/2019.

xiii. Helmenstine, A. M. (2019). Chemistry. Retrieved from https://www.thoughtco.com/what-is-chemistry-602019 on $24 / 04 / 2019$

xiv. Keith, C. L. (2004) the impact of school media centres on academic achievements. Retrieved from http://www.sciences-en-ligne.com on 12/02/2019. 
xv. Kumer and Kaour (2006). Internet Use by Teachers and Students in Engineering Colleges of Punjab, Haryana and Himachal Pradesh: An Analysis. Retrieved from https://journals.sagepub.comon24/04/2019.

xvi. Mami, S. and Hatami-Zad, A. (2014). Investigating the effect of Internet Addiction on Social Skills and in High School Students' Achievement. International J. Soc. Sci. \& Education, 4, 56-61. ISSN: 2223-4934 E and 2227393X Print.

xvii. Mwiria, K. (1985). The Harambee School Movement: A historical perspective. Unpublished Ph.D. Thesis, University of Wisconsin. Newton, D. E. Retrievedfromhttps://www.tused.org. on 12/02/2019.

xviii. Nakhanu, S. B. (2012). Effect of Syllabus Coverage on Secondary School Students' Performance in Mathematics in Kenya. Masinde Muliro University of Science and Technology, Kenya. Int J Edu Sci, 4(1): 31-34 (2012).

xix. Nambuya O. B. (2013). School Based Factors Influencing Student's Academic

xx. Performance at Kenya Certificate of Secondary Education in Teso South District. Unpublished M. Ed Thesis, University of Nairobi.

xxi. Ogedebe, P. M. (2012). Internet Usage and Students' Academic Performance in Nigeria Tertiary Institutions: A Case Study of University of Maiduguri. Academic Research International, 2(3), pp; 334-343, ISSN-L: 2223-9553, ISSN: 2223-9944. SAVAP International.

xxii. Ola, J. R. (1990). The Place of School Library in the New 6-3.3-4 Educational System. Teachers Journal Ondo State ANCOPSS (2nd Ed), Ibadan, Evans Brothers Nigeria Publishers.

xxiii. Plessis, D. P. (2014) Problems and complexities in rural schools: Challenges of education and social development. University of Johannesburg. School of social science. Retrieved from https://www.educationevolving.org on 12/02/2019.

xxiv. Popoola, T. A. (1989). An Investigation between Instructional Resources and Academic Performance. Unpublished M.Ed. Project, University of Ilorin. Retrieved from ～www.journals.savap.org. on 12/02/2019.

xxv. RogersK., Green E. R.,and Joshi S. H. (2018). Biology. Retrieved from https://www.britannica.com/science/biologyon 24/04/2019.

xxvi. Ruth, A. A. and Adedotun, A. (2015). Perceived Influence of Information Sources Availability and Use on the Academic Performance of Secondary School Students in a Nigerian Metropolitan City. American Journal of Educational Research, 3(11), 1346-1349.

xxvii. Siraj, H. H., Salam, A., Hasan, N. A., Jin, T. H., Roslan, R. B. and Othman, M. N. B. (2015). Internet Usage and Academic Performance: A Study in a Malaysian Public University Japan Health Sciences University \& Japan International Cultural Exchange Foundation.30 International Medical Journal, 22(2), 83 - 86.

xxviii. Smith, P. L. and Ragan, T. R. (1999). Principles of instructional design. Columbus, Ohio: Merril

xxix. Torres-Díaz, J., Duart, J. M., Gómez-Alvarado, H. F., Marín-Gutiérrez, I. and Segarra-Faggioni, V. (2016). Internet Use and Academic Success in University Students. Media Education Research Journal. (2), 105-114

xxx. Ullah, S.Z., \&Faroog, M. S.(2008). Quality libraries produce quality learners.

xxxi. Journal of Quality and Technology Management, 4(2), 1-9.

xxxii. Wallin, D. C and Reiner, L. (2008). Educational priorities and capacity. A rural perspective. Canadian Journal of Education, 31(3), 591-612.

xxxiii. Williams, J. D. (2000). Standards of care: Investments to improve children's educational outcomes in Latin America. Paper presented at the 'Year 2000 Conference of Early Childhood Development' Washington, D.C., World Bank. 